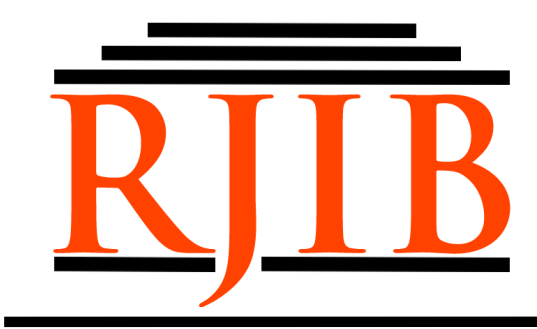

RETORIKA: Jurnal Ilmu Bahasa

Vol. 5, No. 1 April 2019, Page 68-71

\title{
Ambiguity in Writing Story Text of Experience of Grade IV Students of the Champion School Denpasar-Bali
}

\author{
Bonefantura Anggur \\ Magister of Linguistic, Universitas Warmadewa, Denpasar, Bali-Indonesia \\ anggurefhand@gmail.com
}

\begin{tabular}{|l|}
\hline Received: $15 / 09 / 2018 \quad$ Revised:08/04/2019 Published: 30/04/2019 \\
\hline How to cite (in APA style): \\
Anggur, B. (2019). Ambiguity in Writing Story Text of Experience of Grade IV Students of the Champion School \\
Denpasar-Bali. RETORIKA: Jurnal Ilmu Bahasa, 5(1), 68-71. doi: http://dx.doi.org/10.22225/jr.5.1.807.68-71 \\
\hline
\end{tabular}

\begin{abstract}
This research aims is to describe the lexical ambiguity, gramatical ambiguity and what factors that influence the writing skills of primary IV students of The Champion Denpasar-Bali. The method of this research is a qualitative approach. The data is obtained by the written story text from the student's experience. The results showed that the type of ambiguity contained is consisted of lexical ambiguity and grammatical ambiguity. Lexical ambiguity is divided into two parts, namely polysemy and homonymy, while grammatical ambiguity is divided into four parts including: grammatical ambiguity caused by grammatical word formation events, grammatical ambiguity in similar phrases, grammatical vocabulary because of sentence context or lack of grammatical context and ambiguity because of the inaccuracy of the grammatical structure. The factors that influence the writing skills of primary IV students of The Champion Denpasar - Bali. First, the use of a foreign language (English) as a daily communication language of students in schools that intervene in Indonesian, which causes the lack of vocabulary that students have so that students find it difficult to write the text of the Indonesian experience stories correctly. Second, family, the assumption that the task of giving lessons to students is only the duty of the teacher to make the family environment rarely train their children to write at home. Third is, intelligence which is related to students' ability to absorb the material taught to them. The fourth is interest related to encouragement, motives, and emotional responses.
\end{abstract}

Keywords: Ambiguity; experience; story; text; writing

\section{INTRODUCTION}

Ambiguity can arise in various variations of writing or speech. There are three main forms of inadequacy, the three are related to phonetics, grammatical, and lexical (Kempson, 1977). The first phonetic assertiveness or phonological (phonetic) level arises due to the intermingling of the sounds of the spoken language. Words that form sentences when pronounced too fast can lead to doubts about their meaning. Each word can mean more than one, can refer to different objects, according to the environment of use.

Ambiguity occurs when both words and sentences have more than one meaning. If it occurs in the level of word it is called lexical ambiguity. In analyzing the lexical ambiguity, it is important to know the lexical meaning (meaning of the word based on the dictionary) of the ambiguous words and the lexical factors that may lead to the lexical ambiguity such as polysemy (when a single word has two or more different but related meaning) and homonymy (when words having the same spelling and pronunciation but completely different meaning) (Ayu, Dharmayanti, Tika, \& Sudana, 2017). For example, the word bang in Indonesian might refer to 'bank', such a form is said to be polyvalency which can be seen from two aspects, polysemy and homonymy. Polysemy is a relation of meaning of a word that has more than one meaning or a word that 
has different meanings but is still in one meaning. Homonyms are words that are the same sound and shape but contain different meanings and meanings. The factors that lead to homonymy are the words that are homogeneous come from different languages or dialects, the words that are homogeneous occur as a result of morphological processes, homographs and homophones are the same as the shape. The three grammatical inaccuracies arise at the level of morphology and syntax, thus this grammatical inaccuracy can be seen with four alternatives namely grammatical inaccuracy caused by grammatical word formation events, grammatical inaccuracies in similar phrases, grammatical inaccuracies because of the sentence context/lack of grammatical context and inaccuracy because of the inaccuracy of the grammatical structure.

Research about ambiguity in semantic science has be done by Degani \& Tokowicz (2010), he found the review examines how interactions of frequency and context manifest themselves in ambiguity that crosses a language boundary and call for the inclusion of language context as a contributing factor. $\mathrm{He}$ also assesses the need for studies that test within- and cross-language ambiguity in the same individuals before strong conclusions can be made about the nature of interactions between frequency, semantic context, and language context (Degani \& Tokowicz, 2010). Another research by Chinelo (2015) is analyses of intra-textual relations between ambiguous fragments of headlines and their appertaining leads show that lexical choices are made from paradigmatically organized resources. The ambiguous lexical items inter-connect with their alternative expressions in the ensuing texts, with the latter clarifying and illuminating the former (Chinelo, 2015). Setiawan (2014) in his research found that EFL students tend to make ambiguous statement, especially in uncertainly as the most ambiguity types. based on the research, their teacher are recommended to emphasize student with more intensive writing assignment together with peer feedback to measure their writing understanding (Setiawan, 2014).

Based on the background, this research has limits on written text (writing skills) of the elementary school students who do not have ability to write, especially experience story text of Indonesian language. This research analyze the lexical ambiguity in the experience story text, the grammatical ambiguity in the experience story text and what factors that influence the writing skills of primary IV students of The Champion Denpasar - Bali.

\section{METHOD}

This research uses a qualitative approach, with the scope of the study of students' writing about experience stories. The data obtained in the form of written data is the experience story text of primary IV students of The Champion Denpasar-Bali. The method used in this research is explained below. First, researchers do research planning, namely the design of what will be given to students related to writing assignments. When planning the researcher chooses material about writing experience story texts. Second is the implementation, at this stage of the implementation the researcher assigns the task to students to write the story text of experience. In this implementation phase the students who were present consisted of fifteen students. Data from these were analyzed by researchers.

\section{RESULT AND DISCUSSION}

\section{Lexical and Grammar Ambiguity in the Experience Story Text}

The kind of ambiguity in the experiences story text of fourth grade students of The Champion Primary School Denpasar - Bali is divided into two forms, namely the ambiguity of the grammatical level and the ambiguity of the lexical level. In addition to ambiguity, the factors that influence the writing skills of story experiences of students are also explained in this section.

1. Lexical inaccuracies that occur in meaning relationships in the form of polysemy.

"Saya pulang dengan keluarga"/I go home with my family.

Broadly speaking the word "keluarga" or family has different meanings if it is in a sentence. The following explanation provides valid understanding for the reader.

a) Father, mother, sister.

The family meant this time was the smallest unit of the community consisting of the head of the family and several people who were collected and lived somewhere under a roof in a state of mutual dependence.

b) Relatives (e.g. family in one agency).

The term family in a broad sense other than the meaning described in the first discussion is a particular unit in the community which consists of one agency, one community 
organization.

2. Lexical inaccuracy occurs in the relation of meaning in the form of homonymy.

"Orang tua saya sudah capai"/ (My parents have reached)

There is an absence in the word "capai/ reach" in the sentence above. In detail are explained below.

a) Get to the destination.

The word tired can be said to have arrived at the destination.

b) Feeling tired.

Achievement also means tired or tired because of the activities that have been done. Usually if we have done various activities, we usually feel our body is tired.

c) Obtain (get) something with effort.

Achieving also means having gained something with business.

3. Grammatical inaccuracy caused by grammatical word formation events.

"He likes to play with my game".

a) The word game refers to the tools used to play (a device used as a medium to play) by

children such as cars, dolls.

b) The type of play activities that children do like jumping, hide and seek.

This type of physical play is often done by children.

c) Types of games that are on smart phones (smart phones).

The rapid development of technology allows the expansion of the meaning of the game which in the beginning the game refers to things that are real but in the present time the game can also refer to things that are online (in the network).

4. Grammatical inaccuracies in similar phrases.

"Hari ke dua saya pergi ke tiga viharal "The second day I went to three monasteries"

The form of indecision in the phrase 3 of the above temples is explained below.

a) Go to three different temples to pray.

Going to 3 monasteries in this case is going to three different monasteries, so there are three different monasteries visited without mentioning.

b) Go to the monastery called 3 monasteries to pray.

In the second part, 3 monasteries are defined as the name of a place of worship (vihara) named 3 (three).

5. Grammatical accusation due to sentence context or lack of context.

"Malam hari dia tidur di bawah tempat tidurku/ 'At night he sleeps under my bed'

a) Being at the end of the bed just below the feet of the sleeping person.

b) Under the bed

c) Next to the bed

6. Grammatical accusation because of the inaccuracy of the grammatical structure.

"I went to a place to sell dogs my mother bought a white dog."/Saya pergi ke tempat menjual anjing ibuku membeli anjing yang berwarna putih".

The sentence above means ambiguous, the reader will be very difficult to understand what the author means. As an alternative the above sentence can mean the following:

a) "I went to the place to sell dogs, my mother bought a white dog.

This first alternative can mean that the subject "I" did the activity, namely going to a place that sells dogs, until there his mother bought a white dog.

b) "I went to the place to sell my mother's dog, bought a white dog".

The second alternative sentence above explains that the subject "I" went to the place to sell his mother's dog. So in this sentence the dog sells his mother and when he arrived at the place to sell his mother's dog he bought a white dog.

Factors that Influence the Writing Ability of Fourth Grade Students' of The Champion Denpasar Bali.

Foreign Language Usage (English)

Daily communication of all students and teachers of The Champion School uses English as the language of instruction. This certainly interferes with the Indonesian language so that it causes a lack of vocabulary that students have so that students find it difficult to write the text of the experience story in Indonesian correctly.

The following are examples of English terms that students include more in their writing.

1. The end - Use of the end phrase is used to 
finish writing by a student.

2. Sea food - Used to explain the type of food that comes from the sea.

\section{Intelligence}

Intelligence or ability of The Champion School elementary school students in writing text stories of experiences also have an impact on students. This can be the most dominant factor related to student skills. The inability of the brain to think makes students unable to express the experience they have experienced through writing stories of experiences that have been experienced.

\section{Student Interest}

Students in grade 4 of SD The Champion have a low interest in writing text experience stories, this is evidenced by the results of their work that is not optimal. There are still many language errors contained in the text they write. They also have not been able to write the text correctly in accordance with the rules of the Indonesian language that are standardized based on the Indonesian Spelling pedigree (Ejaan Bahasa Indonesia).

\section{CONCLUSION}

Based on the results of the discussion on the main issues described in chapter IV, it can be concluded as follows:

There is a lexical assertion in the writing of the fourth grade students of SD The Champion Denpasar Bali. The types of coercion are often called polyvalence which is divided into two parts, namely polysemy and homonymy. Polysemy is related to the meaning relation of a word that has more than one meaning or a word that has different meanings but is still in one meaning, while homonymy is related to words that have the same sound and shape but contain different meanings and meanings.

In addition to lexical appraisal, the text of the story of the experiences of elementary school students of The Champion Denpasar Bali also contains grammatical indecision. Grammatical inaccuracy arises at the level of morphology and syntax. Grammatical inaccuracy is divided into four parts, namely grammatical inaccuracy caused by grammatical word formation events, grammatical inaccuracies in similar phrases, grammatical inaccuracies because of the context of sentences, and grammatical inaccuracies due to inaccuracies in grammatical structures.

The factors that influence the writing skills are the stories of the experiences of fourth grade students of SD The Champion Denpasar - Bali. First, the use of a foreign language (English) as a daily communication language of students in schools that intervene in Indonesian, which causes the lack of vocabulary that students have so that students find it difficult to write the text of the Indonesian experience stories correctly. Second, family, the assumption that the task of giving lessons to students is only the duty of the teacher to make the family environment rarely train their children to write at home. Third is, intelligence which is related to students' ability to absorb the material taught to them. The fourth is interest related to encouragement, motives, and emotional responses.

\section{REFERENCES}

Ayu, I. G., Dharmayanti, D., Tika, I. K., \& Sudana, I. G. P. (2017). Lexical Ambiguity in English Advertisement Slogans of Unilever Products. Jurnal Humanis, Fakultas Ilmu Budaya Unud, 19(1), 93-101.

Chinelo, J. E. (2015). Headline Ambiguity as a Stylo-Semantic Device in Newspaper Texts. World Journal of Management and Behavioral Studies, 3(2), 44-51. https:// doi.org/10.5829/idosi.wjmbs.2015.3.2.1319

Degani, T., \& Tokowicz, N. (2010). Semantic Ambiguity within and across Languages: An Integrative Review. Quarterly Journal of Experimental Psychology. Retrieved from https://doi.org/10.1080/17470210903377372

Kempson, R. (1977). Semantic Theory. Cambridge: Cambridge University Press.

Setiawan, R. G. (2014). Investigating ambiguity in efl student writing. Repository Universitas Kristen Satya Wacana, 1-26. 